\title{
Books for Review
}

Anthropology in Action is always happy to hear from potential reviewers at all stages in their academic careers.

We currently have a number of books awaiting review. If you are interested in reviewing any of the books on the list below, please contact the reviews editor David Orr (d.orr@sussex.ac.uk). We welcome reviews of around 600 words for a single book, but we are also keen to include review articles comparing two or more works, for which the word length is negotiable. Please also be aware that we can request recent publications (within the last year) from publishers, so do feel free to let us know of any books that you would like to review within the field of applied anthropology, and we will do our best to get them for you. Also note that publishers routinely send pdf or e-copies of publications rather than hard copies.

Beyond books, we are particularly keen to broaden reviews in future issues to other topical content with relevance to applied anthropology, including exhibitions, films, websites, blogs and events. Furthermore, in addition to regular reviews, upcoming issues will feature occasional reviews under the title 'To See Ourselves as Others See Us'. In these reviews, nonanthropologists will review anthropological books and other works, and discuss the contribution they make in the light of their own perspectives and fields. The impetus for this feature lies in the challenges that applied anthropologists often face in explaining and promoting the value of anthropological knowledge outside the discipline. We hope that this invitation to reviewers from outside the discipline will provide readers with stimulating and informative responses regarding how anthropological insights are received in the wider world and regarding how the wider communication of our research could be enhanced.

If you would like to contribute to the occasional reviews feature, or if there is something that you would especially like to review (including content other than books), please do get in touch with us to discuss!

\section{Books currently available and awaiting review include:}

Biehl, J. and P. Locke (eds.) (2017), Unfinished: The Anthropology of Becoming (Durham, NC: Duke University Press).

Bowen, J. R. (2016), On British Islam: Religion, Law, and Everyday Practice in Shari'a Councils (Oxford: Princeton University Press).

Chou, C. and M. K. Zeitzen (2018), Breast Cancer Meanings: Journeys across Asia (Copenhagen: NIAS Press).

De La Piedra, M., Araujo, B. and Esquinca, A. (2018), Educating across Borders: The Case of a Dual Language Program on the US-Mexico Border (Tucson: University of Arizona Press).

Hull, E. (2017), Contingent Citizens: Professional Aspiration in a South African Hospital (London: Bloomsbury).

Josephides, L. and A. S. Gronseth (eds.) (2017) The Ethics of Knowledge Creation: Transactions, Relations and Persons (Oxford: Berghahn).

Lawrance, B. N. and J. Stevens (eds.) (2017), Citizenship in Question: Evidentiary Birthright and Statelessness (Durham, NC: Duke University Press).

Llamojha Mitma, M. and J. P. Heilman (2016), Now Peru Is Mine: The Life and Times of a Campesino Activist (Durham, NC: Duke University Press).

MacClancy, J. (ed.) (2017), Anthropology and Public Service: The UK Experience (Oxford: Berghahn).

Maes, K. (2017), The Lives of Community Health Workers: Local Labor and Global Health in Urban Ethiopia (New York: Routledge).

Mascarenhas, M. (2017), New Humanitarianism and the Crisis of Charity: Good Intentions on the Road to Help (Bloomington: Indiana University Press).

Ong, A. (2016), Fungible Life: Experiment in the Asian City of Life (Durham, NC: Duke University Press).

Pink, S. and S. Abram (eds.) (2015), Media, Anthropology and Public Engagement (New York: Berghahn).

Plemons, E. (2017), The Look of a Woman: Facial Feminization Surgery and the Aims of Trans-Medicine (Durham, NC: Duke University Press).

Anthropology in Action, 25, no. 3 (Winter 2018): 55-56 (C) Berghahn Books and the Association for Anthropology in Action ISSN 0967-201X (Print) ISSN 1752-2285 (Online) doi:10.3167/aia.2018.250307 
Povinelli, E. A. (2016), Geontologies: A Requiem to Late Liberalism (Durham, NC: Duke University Press).

Smith, C. A. (2016), Afro-Paradise: Blackness, Violence, and Performance in Brazil (Urbana: University of Illinois Press).
Weston, K. (2017), Animate Planet: Making Visceral Sense of Living in a High-Tech Ecologically Damaged World (Durham, NC: Duke University Press).

Zerubavel, E. (2018), Taken for Granted: The Remarkable Power of the Unremarkable (Princeton, NJ: Princeton University Press). 